\title{
The Negligence Liability of Public Authorities for Omissions
}

\begin{abstract}
In this article I address the question of whether the omissions principle - the principle that the common law does not impose liability for omissions - applies with the same force in negligence cases involving public authority defendants as in cases involving private defendants. My argument is that the answer depends upon the answer to a prior question: can a duty of care be based upon the public law powers and duties of a public authority? In making my argument, I refute the views both of those who insist that a claim in negligence against a public authority can be rejected purely because it relates to an omission not falling within one of the standard exceptions to the omissions principle and of those who insist that such a claim can succeed while at the same denying that a duty of care can be based on a public authority's public law powers and duties.
\end{abstract}

\section{Introduction}

\section{A. The Problem: the Relationship between the Omissions Principle and Public Authority Liability}

Suppose that a public authority fails to protect a citizen against some harm from which it is the function of the authority to protect her. Suppose, for example, that a police force fails to protect a citizen from a crime or that the fire brigade fails to come to the aid of a citizen whose house is burning. Does the fact of the authority's failure being an omission exempt the authority from liability in negligence in just the way it would if the failure was that of a neighbour who had the capacity to render assistance but failed to do so? In other words, is the authority exempt from liability by reason of the omissions principle, the principle, that is, that the common law does not impose liability for omissions? If, conversely, a court were to hold the authority liable, would this represent the abrogation of the principle? Would it mean that a public authority could be held liable wherever it had the capacity to prevent some harm to a citizen and failed to do so? Or would it represent some special exception to the principle?

The answer I shall give in this article is that whether or not the omissions principle applies to public authorities as it does to private persons depends upon the answer given to a prior question: can a duty of care be based upon the public law powers and duties of a public authority? If it can then where the claim made is that the authority has failed in the performance of one of its assigned functions, the rationale that supports the omissions principle ceases to apply and the authority can be liable for omissions as well as acts, regardless of whether the omissions complained of fall within any of the principle's established exceptions. If it cannot, then the rationale that supports the omissions principle applies just as it would to a private person and only where the omissions complained of fall within one of the established exceptions will it be possible for liability to arise. The aim of the article is thus deflationary or prophylactic. It attempts to remove the omissions principle from the prominent position given to it by some commentators and to redirect attention to what I contend is a more important issue: the relationship between the public law powers and duties of public authorities and the duty of care. 


\section{B. The Problem in Context}

The questions I set out above have received a fair amount of attention in recent case law and commentary. In Michael v Chief Constable of South Wales, ${ }^{1}$ the Supreme Court held that the police were not liable in negligence for their failure to intervene timeously so as to prevent the murder of a woman by her violent ex-boyfriend. The omissions principle figured prominently in the reasoning of the majority. ${ }^{2}$ Lord Kerr and Lady Hale dissented, however, and in doing so they cited with approval an article by Tofaris and Steel arguing that the principle has only limited application to public authorities. $^{3}$

It is easy to see why one might treat public authorities as not subject to the omissions principle. The most commonly advanced justifications for the principle are that to require one person to assist another is an invasion of that person's freedom or personal autonomy and what Lord Hoffmann in Stovin $v$ Wise $e^{4}$ called the 'why pick on me?' argument i.e. the argument that where there is a large or indeterminate class of people able to render assistance to a person in need, there is no reason why one member of the class rather than another should be held liable. Neither of these justifications works when applied to public authorities. Public authorities are not entitled to personal autonomy and where they exist for the very purpose of rendering the kind of assistance that a person in need requires, there is a good reason for picking on them.

Yet opposed to this is the view advanced by Nolan in an article entitled 'The Liability of Public Authorities for Failing to Confer Benefits'. ${ }^{5}$ Nolan argues that the distinction between acts and omissions is a fundamental one that applies irrespective of whether the defendant is a private person or a public authority and that the tendency to neglect the issue and to concentrate instead on the role of public law principles in negligence or on the validity of policy arguments is a mistake. ${ }^{6}$ Nolan is

${ }^{1}$ [2015] UKSC 2; [2015] 2 WLR 343.

${ }^{2}$ See especially [97]-[102].

${ }^{3}$ S Tofaris and S Steele 'Negligence Liability for Omissions and the Police' [2016] CLJ 128. Like a number of other writers on the subject, Tofaris and Steel define the omissions principle so as to include a list of standard exceptions. Their definition, which was approved by Lord Kerr and Lady Hale in Michael is as follows: '[i]n the tort of negligence, a person A is not under a duty to take care to prevent harm occurring to person B through a source of danger not created by A unless (i) A has assumed responsibility to protect B from that danger, (ii) A has done something that prevents another from protecting B from that danger, (iii) A has a special level of control over that source of danger, or (iv) A's status created an obligation to protect B from that danger.' In this article, because I wish to emphasise the detachability of the exceptions from the basic prohibition, I use the expression 'omissions principle' to refer only to the latter.

${ }^{4}$ [1996] AC 923, HL.

${ }^{5}$ (2011) 127 LQR 260.

${ }^{6}$ In the most recent edition of their tort textbook, Nolan and Oliphant make references to the Tofaris and Steel and to the Nolan article referred to above and ask roughly the question of the present article: 'should the omissions principle apply with the same force in cases involving public authority defendants as in cases involving private defendants?' See M Lunney, D Nolan and K Oliphant Tort Law: Text and Materials (6 $6^{\text {th }}$ edn by Nolan and Oliphant, OUP 2017) pp 546-47. 
not alone in asserting that the rule against liability for omissions is, by itself, a fundamental barrier to attaching liability to a public authority in a case in which it causes harm by an omission. In her article 'In Defence of the Omissions Rule in Public Authority Negligence Claims ${ }^{7}$ Hannah Wilberg argues that the rule (or principle as I have called it) apply in the same way to private and public defendants. Elsewhere, one finds at various places in the literature the assertion that to allow liability for omissions in cases involving public authorities will undermine the omissions principle and lead to a state of affairs in which each of us owes a duty 'to all the world'. ${ }^{8}$

The view I express in this article has implications both for the arguments advanced on this issue by Nolan and for those of Tofaris and Steel. It means, on the one hand, that the omissions principle does not have the priority ascribed to it by Nolan. A claim based on harm caused by a public authority's failure to act cannot be rejected purely on the basis that the failure is an omission falling outside the established exceptions. The courts must first be prepared to affirm - as they have done since the Gorringe case $^{9}$ - that a duty of care cannot be based on a public authority's public law powers and duties or, if they are not prepared to affirm this, then that a duty of care based on the authority's public law powers and duties is excluded on policy grounds. So far as the arguments of Tofaris and Steel are concerned, my view entails that their promotion of the view that the omissions principle does not apply to public authorities is only supportable if it is seen as based on a more far-reaching proposition: that a duty of care can be based on a public authority's public law powers and duties. This entails in turn, that the restrictive position taken in Gorringe is mistaken and that the courts should return to allowing the possibility of claims based on public authorities' public law powers and duties as they did for the quarter century before Gorringe was decided. As we shall see, Tofaris and Steel stop some way short of this conclusion.

\section{The Plan of the Article}

As indicated above, the thesis of this article is that whether or not the omissions principle applies to public authorities as it does to private persons depends upon whether a duty of care can be based on a public authority's public law powers and duties. In section 2, I explain what the view that a duty of care can be based on a

\footnotetext{
${ }^{7}$ (2011) 19 TLJ 159.

${ }^{8}$ See, for example, J Smith and P Burns 'Donoghue v Stevenson - The Not So Golden Anniversary' (1983) 46 MLR 147 at 156; J Sopinka, 'The Liability of Public Authorities: Drawing the Line' (1993) 1 Tort Law Rev 123 at 148-9. One set of views that I shall not consider in this article are those of rights theorists such as Robert Stevens and Allan Beever. These authors argue that, beyond the commonly accepted list of exceptions to the omission principle, there is no liability for omissions because we do not have rights that others act so as to assist us. To rebut their arguments would require more prolonged treatment than I can give them here but in a nutshell, they are quite unable to supply arguments to support their view of which rights we have. For Stevens and Beever's views on omissions, see $\mathrm{R}$ Stevens Torts and Rights (OUP, 2007) p 9; A Beever Rediscovering the Law of Negligence (Oxford: Hart, 2007) chapter 9. For critique of the rights theorists attempts to justify their view of the rights we have, see T Cornford 'Public Authority Liability and the Heteronomy of Tort Law' (2013) 21 TLJ 16 pp 22-30.
}

${ }^{9}$ Gorringe v Calderdale Borough Council [2004] UKHL 15, [2004] 1 WLR 1057. 
public authority's public law powers and duties entails and examine the converse view that a duty of care cannot be based on a public authority's public law powers and duties. In section 3, I review the question of what an omission is and the rationale for the omissions principle. In section 4, I bring the arguments of the preceding two sections together to make good the article's basic thesis. The remainder of the article is devoted to rebutting views that conflict with the position reached in section 4 . In section 5, I address arguments to the effect that the omissions principle applies to public as it does to private defendants irrespective of the differences between them. A touchstone for commentators propounding this view is Tony Honoré's well known essay 'Are Omissions Less Culpable?' ${ }^{10}$ I shall argue that this essay does not show what it is believed to show and that the conclusions of the previous section therefore remain unscathed. In section 6, I criticise Tofaris and Steel's approach to the omissions problem on the ground that they studiously avoid the conclusion I argue for in the rest of the article, namely that public authorities are exempt from the omissions principle just to the extent that it is possible to impose on them duties of care continuous with their public law powers and duties. ${ }^{11}$

\section{The Relationship between a Public Authority's Public Law Powers and Duties and the Duty of Care}

In Gorringe, Lord Hoffmann, with whom the other members of the House of Lords agreed said, 'I find it difficult to imagine a case in which a common law duty can be founded simply upon the failure (however irrational) to provide some benefit which a public authority has power (or a public law duty) to provide.' ${ }^{12}$ Lord Scott went further: ${ }^{13}$

In my opinion, if a statutory duty does not give rise to a private right to sue for breach, the duty cannot create a duty of care that would not have been owed at common law if the statute were not there. If the policy of the statute is not consistent with the creation of a statutory liability to pay compensation for damage caused by a breach of the statutory duty, the same policy would, in my opinion, exclude the use of the statutory duty in order to create a common law duty of care that would be broken by a failure to perform the statutory duty. I would respectfully accept Lord Browne-Wilkinson's comment in X (Minors) v Bedfordshire County Council, at p.739, that 'the question whether there is

\footnotetext{
${ }^{10}$ T Honoré 'Are Omissions Less Culpable?' in P Cane and J Stapleton eds Essays for Patrick Atiyah (Oxford, Clarendon Press 1991).

${ }^{11}$ Just to be clear, I shall not argue that courts should impose on public authorities duties continuous with their public law powers and duties. I do in fact think that they should but in this article, for reasons of space, I confine myself to the argument set out in the text above.

${ }^{12}$ Gorringe $\mathrm{n} 9$ above at [32].

${ }^{13}$ ibid [71].
} 
such a common law duty and if so, its ambit, must be profoundly influenced by the statutory framework with which the acts complained of were done.' But that comment cannot be applied to a case where the defendant had done nothing at all to create the duty of care and all that is relied on to create it is the existence of the statutory duty. In short, I do not accept that a common law duty of care can grow parasitically out of a statutory duty not intended to be owed to individuals.

To see how a common law duty of care can be founded on the failure to provide some benefit which a public authority has a power or duty to provide - or 'grow parasitically' out of such a power or duty - it is helpful to look back to the case to which Gorringe was a kind of sequel, Stovin $v$ Wise. ${ }^{14}$ The latter, it will be recalled, concerned a road accident at a junction. The plaintiff suffered injury when a car emerging from a side road knocked him from his motorcycle. Part of the reason for the accident was that at the junction in question, the motorist's vision was obscured by the presence of a mound of earth. The plaintiff brought his action against both the motorist and the highway authority, Norfolk County Council. The latter had powers under the Highways Act 1980 to serve a notice requiring the occupier of the land on which the mound was situated to remove it in order to improve the safety of the junction. It had, in fact, planned to do this work itself but had failed, apparently through pure inadvertence, to execute its plan.

The case raised in an especially clear form the problem of whether a duty of care can be founded on a public authority's public law powers and duties. If the highway authority were treated as if it were a private person then there were no grounds for imposing a duty of care. The Highways Act provided the authority with a panoply of powers for dealing with dangers, obstructions and inconveniences on the highway and the power to order removal of the mound was one of these. It also had a duty under the Act to maintain the highway itself. But there was no explicitly stated duty to remove obstructions to vision at junctions nor any more general explicit duty to deal with dangers and obstructions. On the facts of the case, there was thus no duty of the sort that could form the basis of an action for breach of statutory duty.

In circumstances of this type, the only justification for imposing a duty of care is that the common law duty of care gives effect to a public law duty, the latter not to be found in terms in the governing statute but itself imposed upon or ascribed to the authority on the basis of an exercise in statutory interpretation undertaken by the court. In a case involving a highway authority's power to remove dangers, obstructions and inconveniences on the highway, such as Stovin, the exercise would involve something like the following. A highway authority has many such powers. Clearly it is given these powers for a purpose. It is not at liberty to shirk their use and to simply ignore problems on the highway that they might be used to solve. One way of expressing this would be to say that the authority has an overarching duty to make the highway safe, even though no such duty is expressed in terms in the governing

\footnotetext{
${ }^{14} \mathrm{n} 4$ above. In this sentence I talk simply of a public authority's powers and duties. In the two passages quoted, Lord Hoffmann talks of 'public law' duties and Lord Scott of 'statutory' duties. I address the question of the relationship between public and statutory powers and duties below.
} 
statute. ${ }^{15}$ A duty of this sort would be a target duty leaving a great deal of discretion to the authority as to how to fulfil it. Nonetheless, in the light of this overarching duty or purpose, a court will sometimes feel it appropriate to find that the authority ought to exercise one of its powers, generally on the ground that not to do so would be irrational. On the facts of Stovin itself, it was arguably irrational for the authority, having identified the danger at the junction and having put on foot a scheme for its removal, not to do so. On this basis, it would have been possible to find a public law duty to complete the scheme but also, since not completing the scheme entailed the possibility of foreseeable harm, a duty of care. The content of the public law duty and the duty of care would have been identical.

In his judgment in Stovin, Lord Hoffmann recognized the possibility that a duty of care could be imposed on the basis of reasons like those I have set out in the previous paragraph. He thought that a duty of care could be based on the existence of a statutory power if 'it would in the circumstances have been irrational not to have exercised that power, so that there was in effect a public law duty to act' ${ }^{16} \mathrm{He}$ also thought, however, that for there to be a duty of care it would have to be required by what he called the 'policy of the act'. Where the act did not contain a duty of the sort capable of giving rise to an action for breach of statutory duty, there would have to be exceptional grounds for holding, despite this absence, that a duty of care was appropriate. On the facts of the case he found that there were no such grounds and also that the authority's failure to carry out its scheme of improvement was not irrational.

The majority agreed with Lord Hoffmann. By contrast, Lord Nicholls (with whom Lord Slynn agreed) was prepared in his dissenting speech to take up the idea of a duty of care identical with the authority's public law duty and to develop it. The authority, he found, 'acted in a way no reasonable authority would have done' and 'failed to fulfil its public law obligations just as much as if it were in breach of a statutory duty. ${ }^{17}$ In principle, there was no difficulty in imposing a duty of care because, 'the extent of the obligation would march hand in hand with the authority's public law obligations. ${ }^{18}$ Lord Nicholls accepted that a significant feature of the case was the absence of any indication that Parliament intended there to be a right of action for failure to fulfil the duties in the statute. He thought this feature pointed away from there being a concurrent common law duty sounding in damages. He also thought, however, that there could exist special circumstances that would overcome this

\footnotetext{
${ }^{15}$ In postulating the existence of such a duty one would also take into account powers and duties in other relevant statutes such as the duty on highway authorities that are local authorities in s 39 of the Road Traffic Act 1988 to carry out studies into road accidents in its area and to take such measures as appear to it to be appropriate to prevent them.

${ }^{16}$ Stovin (n 4) at p 953 D-E.

${ }^{17}$ ibid p 936.

18 ibid p 936 B.
} 
obstacle and establish proximity between authority and plaintiff. ${ }^{19}$ On the facts of the case, he found that these were present. $^{20}$

A similar style of reasoning to that adopted by Lord Nicholls in Stovin is to be found in the judgements of Lord Woolf in the Court of Appeal in Kent $v$ Griffiths ${ }^{21}$ and Larner v Solihull Metropolitan Borough Council ${ }^{22}$ and in the judgment of the Court of Appeal without Lord Woolf in Gorringe. ${ }^{23}$ The essential ingredients that make up the approach adopted by Lord Nicholls in Stovin and emulated in the cases mentioned may be summarised as follows. In each case there is no relationship between claimant and defendant capable of giving rise to a duty of care on ordinary private law principles. In each case the defendant public authority has statutory powers. The governing statute contains no duty of the sort capable of giving rise to an action for breach of statutory duty. The court, however, by reference to overarching target duties contained in the governing statute or on the basis of a global analysis of the purposes for which the authority's powers are granted or both, holds itself able to ascribe duties to the authority and, on the facts of the case, finds a duty owed to the claimant breach of which has caused foreseeable harm. This public law duty is then identified with a duty of care in negligence.

There are two complementary ways of looking at this approach. One is to see it as tacitly underpinning the law in this area during the whole period inaugurated by the House of Lords' decision in Anns v Merton Borough Council ${ }^{24}$ and ending with Gorringe. In Stovin, Lord Nicholls was quite clear about the significance of Anns in this respect. Before 1978, he said, it had not been possible to find a public authority liable in negligence for failure to exercise a statutory power. The decision in Anns, however, 'liberated the law from this unacceptable yoke' ${ }^{25}$ and 'articulated a response of growing unease over the inability of public law, in some instances, to afford a remedy matching the wrong. Individuals may suffer loss through the carelessness of public bodies in carrying out their public law functions. Sometimes this evokes an intuitive response that the authority ought to make good the loss. ${ }^{26}$

\footnotetext{
19 ibid p 937.

${ }^{20}$ Stovin (n 4) at p 939-41.

${ }^{21}$ [2000] 2 WLR 1158.

22 [2001] RTR 32.

${ }^{23}$ [2002] EWCA Civ 595, [2002] RTR 27.

${ }^{24}$ [1978] AC 728.

${ }^{25}$ Stovin (n 4) p $931 \mathrm{~F}$.

${ }^{26}$ Ibid p 933 F-G . Cf Lord Bingham in his essay 'The Uses of Tort Law' (2010) 1 JETL 3: ‘...if a member of the public whom a public service exists to serve suffers significant injury or loss through the culpable fault or reprehensible failure of that service to act as it should, is it not consistent with ethical and, perhaps, democratic principle that the many, responsible for funding the service, should bear the cost of compensating the victim?'
} 
Since the approach I describe here was not explicitly articulated before Stovin, the law between Anns and Gorringe only embodies it very imperfectly and to treat it as justification for that law clearly involves a degree of interpretative licence. Perhaps in part because of the lack of a fully articulated justification, the courts were not at ease with what they had done in Anns and often sought to avoid its consequences by invoking policy considerations. ${ }^{27}$ It is not altogether surprising, in this respect, that not many years separate Lord Nicholls' adumbration of a public law-based justification for Anns from the decision in Gorringe to close altogether the door that Anns had opened.

The second way of looking at the approach I have described is as a blueprint and guide to the future. If one wanted a theoretical justification for this, it would go something like the following. Public authorities are given special powers in order to serve the public, both the general public as a whole and, in some cases, individual members of it. A special body of law, public law, exists both to facilitate the performance by public authorities of their functions and to hold them to account by ensuring both that they fulfil their duties and that they do not exceed their powers. Where a public authority harms an individual citizen either by acting in excess of its powers or by failing to fulfil a duty that it owes to an individual citizen, the same remedy is appropriate as would be appropriate if one private person had harmed another, namely compensation or damages. In a system which has not traditionally made a clear distinction between public and private law and in which private law proceedings can be used to question the public law lawfulness of acts and omissions of public authorities, there is no reason not to use the law of tort to provide this remedy.

To defend this justification and to draw out all the implications of the approach it supports would require more space than is available here and since my purpose in outlining it is to describe its relation and that of its opposite to the omissions principle, I turn next to the omissions principle's rationale. ${ }^{28}$ Before I do so, however, two features of the approach are worth touching on since they are relevant to the argument that follows. Firstly, I mentioned above the courts' practice in the years following Anns of eliminating by means of policy considerations the possibility of a duty of care that Anns seemed to promise. The public law-based approach considered here is not, however, incompatible with the use of policy considerations to limit the incidence of the duty of care as long as this is genuinely done to prevent the bad consequences that imposing a duty of care might have in particular cases rather than to thwart the approach altogether. Secondly, since the justification adverts to the special powers possessed by public law bodies generally there is no need to think of the approach as being exclusively concerned with public bodies' statutory powers and duties: where, as in the case of the Crown or the police, a body had significant common law public powers, the approach could licence the derivation from these of a duty of care.

\footnotetext{
${ }^{27}$ As they did most notably in Hill v Chief Constable of West Yorkshire [1989] AC 53 and X (Minors) v Bedforshire County Council [1995] AC 633.

${ }^{28}$ I have set out in much greater detail an approach and justification like that describe in the text in my book Towards a Public Law of Tort (Ashgate, 2008).
} 


\section{The Omissions Principle}

\section{A. What is an Omission?}

I begin with the definition of an omission. As Honoré has said, if omissions were to be defined by reference to the rationale underpinning the omissions principle, then it would be true tautologically that an omission was something that could not give rise to liability. ${ }^{29}$ In order, therefore, to give the rule substance it must be possible to identify some neutral distinction between action and inaction that is independent of the rationale.

The key non-normative notion is that of inaction, in the sense of absence of bodily movement, that gives rise to harm i.e. in relation to which it is possible to say that a given instance of harm would not have occurred if the person whose inaction is in issue had acted. This notion encompasses both the case of the passer-by who does nothing to save a child drowning in shallow water and of the person who does not take advantage of the opportunity to walk up to a stranger in the street and offer him a $\$ 100$ bill. ${ }^{30}$ An omission is a case of inaction in relation to which there is some reason to assert that the non-actor ought to have acted. In relation to the examples just given, the first but not generally the second would be thought of as an omission since most of us would recognize, at least, a moral duty to assist a dying child while most of us would deny the existence of an obligation to give money to random strangers. ${ }^{31}$

\footnotetext{
${ }^{29}$ Honoré n 10 above p 37.

${ }^{30}$ To borrow an example from Joel Feinberg: J Feinberg The Moral Limits of the Criminal Law: Volume 1, Harm to Others (Oxford University Press, 1984) p 135.
}

${ }^{31}$ In seeking a basic non-normative concept as a building block for discussion of the omissions principle, I eschew the distinction between harming and failing to confer a benefit. Some writers who insist on the absoluteness of the omissions principle promote this distinction as a straightforward factual one use of which makes it possible to avoid the difficulties associated with the act/omission distinction: see, for example Nolan n 5 above at p 260; M Bowman and S Bailey 'Negligence in the Realms of Public Law - A Positive Obligation to Rescue?' [1984] PL.277, 283. On this view, in order to determine whether a person's blameworthy behaviour is an act or an omission, we need only ask whether she has worsened or merely failed to improve the victim's position. The objection to this view is that we cannot divorce the question of whether someone is improving or worsening another's situation from the question of what that other person is entitled to expect. If A gives B something she is not entitled to expect, we may say that A is conferring a benefit on B or improving B's situation. If A gives B something that she is entitled to expect, it would not be natural to say A is improving B's situation. A will be simply maintaining B's current condition. Everything turns on what B is entitled to expect and determining this involves all the difficulties that are involved in determining whether B's inaction amounts to an omission. The harm/failure to confer a benefit distinction is often used, moreover, in a way that is misleading. On the one hand, to speak of an intervention to assist someone as 'conferring a benefit' tends to suggest that the intervention is something to which the recipient of the assistance is not entitled. On the other hand, users of the notion are in the habit of describing any omission not falling within one of the traditional exceptions to the omissions principle as a failure to confer a benefit. Bailey and Bowman characterize the defendant public authority's failure in Anns v Merton Borough Council in this way, for example, and Nolan does the same in relation to Gorringe. Users of the harm/failure to confer a benefit distinction thus skew discussion in favour of the view that omissions not falling within one of the traditional categories of exception to the omissions rule cannot give rise to liability while at the same time pretending that the distinction has a clear factual basis when it does not. 


\section{B. The Rationale of the Omissions Principle}

The rationale for the principle that omissions do not give rise to liability is correctly expressed in the first two reasons given by Lord Hoffmann in the Stovin case mentioned above: ${ }^{32}$ the first reason is that requiring people to act affirmatively so as to assist others constitutes a greater inroad on their liberty than requiring them to refrain from acting so as to harm others; the second is what Lord Hoffmann calls the 'why pick on me' argument i.e. the fact that there often appears to be no principled way of confining the class of persons who should be subject to an affirmative duty or of deciding which members of the class should bear it. ${ }^{33}$

Honoré attempts to explain the omissions principle in utilitarian terms. ${ }^{34} \mathrm{He}$ suggests that we sanction acts more severely than omissions because abstaining from harmful action requires less effort than acting positively to assist others while the effects of abstention are more widely distributed than the effects of positively providing assistance. Thus it is easy to refrain from poisoning others and it benefits everyone, whereas for an individual to provide food to a starving person might be onerous and would benefit only the individual assisted. The implication is that the net benefit is greater when we require people to refrain from harmful action than it is when we require people to assist others. It is not hard, however, to think of situations where this is not the case. A rule requiring ships in fog to sound their horns presumably has greater net benefit than a rule that simply requires them to avoid hitting each other. Kortmann invites us to consider the example of a busy road blocked by an

\footnotetext{
$32 \mathrm{n} 4$
}

${ }^{33}$ His lordship added a third, economic justification. This was that those carrying out harm-causing activities were required to internalize the costs they imposed on others and that finding liability was a way of making them do so. This made sense, his lordship said, where a defendant positively imposed a cost by harmful action but not where, by failing to act, she failed to confer a benefit. It is doubtful whether English tort law can be explained in economic terms (although see R Posner and W Landes The Economic Structure of Tort Law (Harvard UP, 1987)). But putting this to one side, the dominant school of economic analysis of law does not insist that each activity internalise the costs that, on the basis of traditional legal notions, we would characterize a defendant as imposing on others. Instead, it requires that the necessary precautions or change in behaviour be undertaken by whomever can do so most cheaply. So, for example, if fumes from a factory were damaging the health of neighbouring householders and this damage could be avoided most cheaply by the householders staying indoors and keeping their windows closed, the economic approach would forbid a finding that the factory was liable. If the person who should take steps to avoid accidents or other social harms is the "cheapest cost avoider', it is hard to see why this person should not be someone who could positively intervene so as to prevent the harm as well as someone who could avoid the harm by refraining from action. Of course, to require each person to assist another where her doing so was cheaper than requiring the creator of the harm to take greater care or the victim to bear the loss might create an unmanageable burden and so there would have to rules to decide under what circumstances a given person should be under an affirmative duty. This just takes us back to the Feinberg argument described in the text above. For basic exposition of the economic approach see e.g. R Posner Economic Analysis of Law (9th edn, Kluwer, 2014) chapters 1 and 6; G Calabresi The Cost of Accidents (Yale, 1970); P Cane Atiyah's Accidents, Compensation and the Law (8th ed, Cambridge UP, 2013) pp 435-55. For a discussion of the application of the economic approach to the problem of omissions, see J Kortmann Altruism in Private Law: Liability for Nonfeasance and Negotiorum Gestio (Oxford: OUP, 2004) pp 18-23.

\footnotetext{
${ }^{34} \mathrm{n} 10$ above at $31-32$.
} 
unconscious person..$^{35}$ The total social cost of requiring one driver to remove the unconscious person is lower than the social cost of requiring each driver to steer round her. What does seem clear is that subjecting each of us to myriad duties to help others would create an unsustainable burden. This brings us back to Lord Hoffmann's explanations of the principle. The second of these is usefully elaborated by Feinberg who points out that requiring each of us to render assistance whenever we were able to would not only impose an excessive burden but would create confusion. ${ }^{36}$ This is not, Feinberg argues, a reason for denying the existence of a duty on society as a whole to assist those in need but the task of providing that assistance is divided up on the basis of social rules about who must help whom in which circumstances. As a consequence, we do not usually feel obliged to come to the aid of others unless required to do so by these rules.

The standard exceptions to the omissions principle must be understood as cases in which the rationale for the principle does not apply or in which there are countervailing considerations that override it in the particular case. In each, some factor is present that overcomes the objection that to impose a legal duty to act represents too great an inroad on the liberty of the duty-bearer and each is an example of the way in which the law, by coordinating the allocation of responsibility, avoids the problems that would arise from imposing on each of us a duty to assist others in all circumstances. Where someone has created a harm or a risk of harm, there is a clear reason to 'pick on' that persons as the one who must mitigate or avert it. Doing so involves making an inroad on the harm creator's freedom but it is a justified one since taking responsibility for the effects of one's actions is a necessary incident of freedom. Where a person is obliged to act positively because she has made an undertaking then there is a clear reason to pick on her and there is no inroad on her freedom because she made the undertaking voluntarily. Where an affirmative duty is attached to some role or status, this involves no inroad on freedom since the role or status will generally have been assumed voluntarily in the knowledge of what it entails. The attachment of affirmative duties to particular roles or statuses illustrates especially clearly, moreover, the way in which the general duty to assist others or to avert social harms is parcelled out among individuals. Hence school teachers are made responsible for the welfare while in school of school children, and to some extent also, for preventing the harm that they may cause others; prison officers are responsible for the welfare of prisoners and for preventing the harm the prisoners may cause if they escape; a lifeguard is responsible for saving swimmers who get into trouble; and a landowner has an affirmative duty to deal with a danger or nuisance that originates on her land. As Feinberg argues, in each of these cases, members of the public who do not occupy such positions feel themselves exempt from the affirmative duties that occupancy of the positions entails precisely because they know that those duties have been apportioned to others.

In this context, Honoré makes an important distinction. He distinguishes between background duties, "which we owe to all' ${ }^{37}$ and distinct duties, which are 'duties to

\footnotetext{
${ }^{35}$ Kortmann n 33 above at 19-20.

${ }^{36}$ Feinberg n 30 above, 169-171.

${ }^{37}$ Honoré n 10 above p 33.
} 
other people and associations, including the state, which vary from person to person according to past dealings between them.' At the background level, there is no duty to help others. There are, however, duties to avoid harming others. We might say that the possibility of causing harm to another creates a relationship with that other and that this makes the imposition of a legal duty feasible and appropriate. The duties described in the previous paragraph as constituting exceptions to the omissions principle are examples of distinct duties. ${ }^{38}$ According to Honoré, where a person owes a distinct duty it cannot be assumed that an omission is worse than an act and there may therefore be no reason for the omissions principle to apply. Hence it is as bad for a parent to starve a child as to beat $\mathrm{it}^{39}$ and it may be as bad for a doctor who has undertaken to treat a patient to fail to administer medicine as to give the wrong medicine. ${ }^{40}$ Honoré also observes that 'distinct duties are stronger than the background duties we owe to everyone and take priority over them. ${ }^{41} \mathrm{He}$ does not illustrate this assertion but an example might be, presumably, that a parent's duty to protect her child from physical harm outweighs her duty to avoid causing physical harm to a passer-by in the street.

The omissions principle is, in essence, a doctrine about background duties. It involves repudiation of the principle advanced by some moralists that we are all under an obligation to help anyone who might benefit from our assistance even if it at significant cost to ourselves. ${ }^{42}$ Or to be more precise, it involves repudiation of the idea that it is the function of the law to enforce such an obligation. We may, morally speaking, have obligations of that sort but the law leaves it to the conscience of individuals to decide whether they wish to act on those obligations and values the freedom of the individual over the claims of those in need of assistance.

Honoré's distinction between distinct and background duties helps us see that where it is argued that a particular type of omission should give rise to liability, the argument often rests not on the claim that we owe 'a duty to all the world' but on the claim that the circumstances in question give rise to a distinct duty. This is so, I suggest, in relation to the vexed case of easy rescue. The typical proponent of the view that there should be a duty to undertake easy rescue is not suggesting abolition of the act/omissions distinction, wholesale rejection of the omissions principle or that the potential rescuer owes a duty to all the world. Rather, the proponent is suggesting that where a small number of passers-by are in a position to rescue a person in difficulty without great danger to themselves, they owe a distinct duty to that person. The imagined circumstances are, after all, such as to defeat the reasons for not allowing

\footnotetext{
${ }^{38}$ Honoré's reference to 'past dealings' might be taken to indicate that distinct duties are only those that arise as a result of some form of voluntary undertaking but it is clear from the rest of his essay that he means the expression to refer to the range of generally recognized exceptions to the omissions principle.

${ }^{39}$ Honoré $\mathrm{n} 10$ above p 33.

${ }^{40}$ Ibid pp 48-49.

${ }^{41}$ Ibid p 33.

${ }^{42}$ As for example in Peter Singer's claim that we should all help people in poorer countries up to the point at which the loss to us outweighs the gain to them: see P Singer 'Famine, Affluence and Morality' (1972) 1 Philosophy and Public Affairs 229.
} 
liability for omissions: only a small number of people are eligible to be bearers of the duty and the requirement to effect the rescue does not constitute a significant inroad on their liberty. ${ }^{43}$ As I shall argue below, the claim that a public authority should be liable for an omission is nearly always based on the idea that it owes a distinct duty in Honoré's sense.

\section{Public Authorities and the Omissions Principle}

In part B of the introduction to this article, I outlined some reasons for thinking that the rationale underlying the omissions principle does not apply to public authorities. The significance of this needs to be spelled out more precisely, however. As a general proposition, it is not true that the rationale does not apply to public authorities. At the level of background duties, it does apply. Public authorities do not owe 'duties to all the world'. They are not obliged to help people just because, as a practical matter, they might be capable of doing so. No one claims, for example, that the fire brigade should be liable for harm caused by failure to apprehend criminals or that the ambulance service should be liable for harm caused by failure to paint markings on the road warning of dangers or that a social services department should be liable for harm caused by failure to spot the signs of dyslexia in a child, even though one can imagine circumstances in which each type of authority might be in a position to avert harms of the sort mentioned. It is true, as I emphasized in my introduction, that public authorities have no personal interest in freedom and hence that one part of the rationale for the omissions principle might appear not to apply to them. Against this, however, public authorities are bound by public law to use their powers only for the purposes for which they were granted. They cannot therefore be required or - what is tantamount to the same thing - held liable for failure to use their powers in ways alien to these purposes.

It is in relation to certain types of distinct duty that the argument outlined in the introduction is accurate. A public authority can be liable for an omission that falls within one of the traditional exceptions to the rule against liability for omissions. This is so, at least, where to hold the authority liable would not involve the implication that it ought to have acted in a way contrary to its assigned purpose. ${ }^{44}$ The focus of the argument outlined in the introduction is different, however. It relates precisely to the type of case discussed in section 2 above in which the court ascribes to the defendant public authority an overarching duty or purpose and on this basis deduces the

\footnotetext{
${ }^{43}$ It is not my intention, however, to argue that there is a case for a duty of easy rescue. The argument I wish to make in this article does not depend on showing that there is. My argument is, rather, that in order to support a duty of easy rescue it is not necessary to undermine the omissions principle but merely to make an exception to it; and that, in the say same way, the best argument for public authority liability for omissions falling outside the established exceptions involves making another exception to the principle rather than undermining it.

${ }^{44}$ Barrett v Enfield LBC [1999] 3 WLR 79, HL and Phelps v Hillingdon LBC [2000] 3 WLR 776, HL are examples of the kind of case in which the defendant authority can in principle be held liable for an omission since the omission in question falls within one of the standard exceptions; and in which, at the same time, the duty of care that the authority would be thereby held to have breached is entirely consistent with the authority's public law obligations.
} 
existence of other more particular duties owed to particular persons. Where a public authority has failed to do the kind of thing that it exists to do, there is no danger that by imposing liability the court will require it to act in a way contrary to its assigned purpose (this being, as we saw above, the equivalent in the case of public authorities of the consideration that liability for omissions represents too great an inroad on the freedom of private persons). And because, again, it is the function of the authority to assist the claimant, there can be no 'why pick on me' objection to making it liable. Thus if it is possible to superimpose a duty of care on a statutory - or more generally, public - power or duty, then the objections to liability for an omission are overcome.

In the light of this it is no surprise that some of the leading cases that can be explained in terms of the approach described in section 2 involve omissions. In the Anns case, ${ }^{45}$ for example, and in $X$ (Minors) $v$. Bedfordshire $C C,{ }^{46}$ the possibility of liability for omissions was accepted even though the omissions in question did not fall within any of the traditional exceptions to the omissions principle. In neither case was the omissions principle itself discussed. This lack of discussion was not the result of a dereliction of duty on the part of the courts. ${ }^{47}$ It reflected the fact that the primary issue in these cases was whether the authorities' statutory powers and duties to assist the claimants gave rise to a duty of care to do so.

By the same token, the significance of the Gorringe case does not lie in the fact that it restores the omissions principle to its proper position of salience. It lies in the fact that it excludes the possibility of basing a duty of care on a public authority's public law powers and duties. This entails in turn that the only factors that can militate in favour of imposing a duty of care are those that would apply irrespective of whether the defendant were public or private. And it is only as a side effect of this, that in the present state of the law, a court wishing to impose a duty of care in respect of an omission must show that the omission in question falls within one of the established exceptions. Were we to revert to the position that pertained between the Anns case and Gorringe, then it would again be possible to make an exception to the omissions principle that related specifically to public authorities.

This is the basic answer to those writers mentioned in the introduction to this article who insists that the omissions principle must always apply in the same way whether the defendant is private or public. Nolan claims that attention to whether a public authority has brought about the harm complained of via an act or an omission should precede or take priority over consideration of public law principles or policy arguments. But it is the answer to the latter two questions that will determine how the omissions principle applies. Similarly, Wilberg identifies a set of criteria that are supposed to determine whether there can be liability for an omission in relation to both public and private defendants. But this makes it impossible to see why there is sometimes - as Lord Nicholls put it - an intuitive response that a public authority

\footnotetext{
${ }^{45}$ n 24 above.

${ }^{46}$ n 27 above.

${ }^{47}$ Contrary to the criticism made by Bailey and Bowman of the reasoning in the Anns case in 'Negligence in the Realms of Public Law' n 31 above.
} 
should have acted to assist someone when the same response is lacking in relation to a private person who might have been equally able to assist. ${ }^{48}$

\section{Counterarguments}

This is not all there is to be said, however, on the question of whether the omissions principle applies in the same way to private and to public defendants. Neither Nolan nor Wilberg accept that the kinds of reasons I advanced as justifying the omissions principle - the first and second reasons set out by Lord Hoffmann in Stovin - provide sufficient explanation. Both insist that the principle must have some deeper significance that explains why it should cut across the distinction between public and private. In support of this view, Wilberg invokes the claim that omissions are causally peripheral. For the same purpose, both Wilberg and Nolan pray in aid Tony Honoré's claim that omissions are in general less harmful than acts. Both these claims are mistaken. In this section I attempt to show why.

\section{A. Omissions are Causally Peripheral}

The claim that omissions are causally peripheral originates in an article by Jane Stapleton ${ }^{49}$ and is a central plank of the Wilberg article referred to above. ${ }^{50}$ Wilberg asserts that an omission's status as causally peripheral is part of what defines it as an omission and entails that special requirements must be satisfied if liability is to arise. The implication is of some basic difference that is deeper than the bare difference between action and inaction and that both helps us distinguish omissions from acts and explains why it is generally not appropriate to attach liability to the former.

By describing omissions as causally peripheral, Wilberg means that in the typical omissions case, the defendant will have failed to protect the claimant from some harm and this harm will have been more directly caused by some third party or perhaps by some natural phenomenon. On this view, the defendant's failure to act will be a cause, but a secondary or, as it is put, peripheral one. One has only to think of the case in

\footnotetext{
${ }^{48}$ The criteria identified by Wilberg include a set of exceptions to the omissions principle roughly equivalent to the standard set and she counts amongst these the possession by the defendant of special powers of control over the risk giving rise to the harm to the claimant. She considers the argument that the main justifications advanced for the omissions principle (the 'liberty' and 'why pick on me' arguments) do not apply to public authorities and replies that this objection is overcome by the consideration that, in appropriate cases, public authorities can be made liable for omissions that fall within her set of exceptions, especially the control exception. As noted in the text, however, it is not possible to see why on this view there is sometimes an argument for making a public authority liable when the same argument would not be made in relation to an analogously situated private person. Why, for example, might we argue that the police in Michael should have been liable when we might hesitate to argue the same in relation to a neighbour who would have been in as good a position to assist but did not do so? See further the arguments in section 6 below.

${ }^{49}$ J Stapleton 'Duty of Care: Peripheral Parties and Alternative Opportunities for Deterrence' (1995) 111 LQR 301.

${ }^{50}$ Wilberg n 7.
} 
which the police are blamed for failing to prevent a crime or the fire brigade for failing to put out a fire to see what is meant. Classifying omissions as causally peripheral adds little to what I have already said in this essay about the reasons for the omissions principle, however. Nor does it provide any reason to think that the omissions principle need restrict the liability of public authorities more than I have already suggested it does.

The idea that an omission can only be a cause in a secondary and inferior sense reflects the view that to cause something always involves active participation in bringing it about. ${ }^{51}$ But while it is true that in ordinary usage, we are more inclined to say that someone who omits to protect another has failed to prevent harm than that they have caused it, in law it is accepted that omissions cause harm and most theorists of causation strongly affirm this position. ${ }^{52}$ Since it is clear that omissions can be causes-in-fact, the only grounds for treating them as belonging to a lesser variety of cause must be normative ones. To see what those might be, it is helpful to look at the article by Stapleton on which Wilberg draws. ${ }^{53}$

Stapleton suggests that certain defendants' omissions are causally peripheral in the context of a discussion of how the courts reduce the incidence of the duty of care in negligence cases by refusing to find a duty where the claimant could have done more to protect herself from the harm she suffered. The operative considerations are ones of policy and morality. As a matter of policy, it is desirable to confine the deterrent effects of the duty of care to those able most easily to avoid harm, be they claimants who can help themselves or third parties. At the same time, it is desirable to protect deep-pocketed defendants, often public authorities, from the excessive liability that might attach to them if they were required to protect claimants from their own or third parties' negligence. As a matter of morality, to make many people potentially liable for the negligence of a third party would represent a vast inhibition on freedom. The latter consideration is simply the first of Lord Hoffmann's two reasons for the omissions principle. As we have seen, it can be overridden if a duty of care can be based on a public authority's public law powers and duties. The former considerations are examples of the type of policy argument that can limit the incidence of the duty of care whether or not it can be based on a public authority's public law powers and duties. None of these considerations undermine the basic proposition that there are reasons for making an exception to the omissions principle in relation to public authorities that do not pertain in relation to private persons.

\footnotetext{
${ }^{51}$ Feinberg n 30 above p 180; HLA Hart and T Honoré Causation in the Law (2 $2^{\text {nd }}$ ed, OUP, 1985) p 30 n 4 and accompanying text, p 38, p 140 .

52 See e.g. HLA Hart and T Honoré n 51 above, pp 2, 5, 16, 30-31, 37-38, 50, 59, 62, 81, 127-28, 138 141, 236; Feinberg n 30 above pp 165-85; J Stapleton 'Choosing What We Mean by Causation in the Law' (2008) 73 Missouri Law Review 433, 435-37; J Stapleton 'Unnecessary Causes' (2013) 129 LQR 39, 40; J Stapleton 'An "Extended But-For" Test for the Causal Relation in the Law of Obligations'(2015) 35 OJLS 697, 699, 705, 709. Stapleton convincingly refutes Michael Moore's claim (made for example in 'Causation and Responsibility' (1999) 16 Social Philosophy and Policy 1) that omissions cannot be causes in the first article of hers referred to in this footnote at $\mathrm{p} 467$.

${ }^{53}$ Stapleton (n 49).
} 
In his article on public authority liability for omissions, Nolan invokes Honoré's argument that omissions are in general less harmful than acts. ${ }^{54}$ Prior to making reference to it, Nolan considers briefly the individual liberty and 'why pick on me' justifications for the omissions principle set out by Lord Hoffmann in Stovin. ${ }^{55}$ Neither apply to public authorities, Nolan agrees, but nor are they good justifications for the principle: they do not satisfactorily explain, for example, why an ordinary private person should not be liable for an omission to act in circumstances in which to act would not be unduly burdensome and in which there are no or few other people who could render the assistance required. But, Nolan continues, there are more convincing justifications for the differential treatment of acts and omissions and he cites Honoré's argument 'that in general harmful abstentions are less culpable than wrongful acts, because while the latter constitute inroads on security, the former threaten only the expectation of improvement, a different and secondary value.' Nolan asserts that in the light of this argument, we can conclude that 'there is no justification for distinguishing between public authorities and private parties when it comes to failures to confer benefits and that therefore Gorringe represents a welcome rationalisation of the law. ${ }^{56}$

What exactly is Honoré's argument and does it have the effect ascribed to it by Nolan? It is true that Honoré's fundamental claim in his article is that harmful acts are worse than harmful omissions and that this claim is made on the grounds Nolan mentions. It is very hard to find anything in the article that supports the claim, however. We saw above that Honoré makes a sound and illuminating distinction between the background duties that each of us owes to everyone else and the distinct duties that arise in particular relationships: we have background duties to refrain from harming others but we do not necessarily have background duties to act so as to help others, whereas we may owe distinct duties to help as well as not to harm and, in this latter context, an omission may be worse than a harmful act; distinct duties, moreover, generally take priority over background ones. This is the solid framework of Honoré's article. Onto it he grafts the argument about harmful acts being worse than harmful omissions. What is the relationship between the framework and the argument that Honoré superimposes upon it? Are we to understand that harmful acts are worse than harmful omissions at the level of background duties, at the level of distinct duties or both?

If the argument is intended to show only that harmful acts are worse than harmful omissions - and more of a threat to security - at the level of background duties then it tells us nothing that is not already revealed in the original framework. This can be seen if we consider an example that Honoré seems to think supports his security argument. He says that someone who drops litter is more culpable than someone who fails to pick up the same litter even though the harm caused and the likely effort that

\footnotetext{
${ }^{54}$ Nolan $n 5$ above p 285.

55 ibid p 284.

${ }^{56}$ ibid p 285.
} 
would be required to do the right thing would be the same in each case. ${ }^{57}$ But here Honore is comparing two background duties: the duty that a citizen owes to society as a whole not to drop litter and the duty that a citizen owes to society as a whole to pick up someone else's litter. The greater culpability of breach of the former duty can be explained by the second, 'why pick on me' justification for the original point about background duties. We can see this more clearly if we make a comparison of the relative culpability of someone who drops litter with someone whose job it is to pick up the litter and who fails to do so, thus breaching a distinct duty. Here it is much less clear that a harmful act is worse than a harmful omission.

If, on the other hand, Honoré's security argument is supposed to show that harmful acts are worse than harmful omissions where those omissions are breaches of distinct duties, then it simply contradicts what is said elsewhere in the article. Honoré says very little to support the idea that this is the purpose of the argument. He does give in passing an example consistent with the assumption that it is so: he suggests that a wage cut is worse than the failure to receive a pay rise. ${ }^{58}$ But upon examination this example tends to support the view, advanced earlier in the article by Honoré himself, that in the context of distinct duties an omission may be just as bad as an act. Whether or not receiving a wage cut is worse than not receiving a pay rise depends entirely on the context and what one has been led to expect. If you work in a company that has been doing badly because of the recession and the necessity of a pay cut has been discussed and the pay cut then turns out to be only $5 \%$ of your income, you may be relieved. If, by contrast, you were confidently expecting a Christmas bonus worth $10 \%$ of your income and you have already bought expensive Christmas presents on that assumption then you may be gravely disappointed with a bonus worth only $5 \%$ of your salary. Examples of pairwise comparisons of this sort, demonstrating that in the context of distinct duties an omission may be as damaging to security as an act, can be multiplied indefinitely. ${ }^{59}$

The whole idea that acts represent more of a threat to security than omissions is, moreover, contradicted by what Honore says earlier in the article in establishing the framework. Having set out the view that bodily movement counts as intervention in the world while non-movement does not he writes:

But superimposed on this picture of the world is a refinement of it, which treats disruptions of the normal course of events as similar to interventions which bring about change, though the change is not now a change in the existing state of affairs but rather in the normal or expected sequence of events. The regular course of things may take the form not only of recurrent natural events, but of regular human conduct such as clearing the street when

\footnotetext{
${ }^{57}$ Honoré n 10 above pp 49-50.

58 ibid p 35.

${ }^{59}$ One person is injured by the negligent driving of a motorist, another in a train crash caused by the negligent failure to maintain the track; a haemophiliac loses blood on one occasion because someone carelessly cuts her and on another because she cuts herself and the ambulance she calls fail to arrive; one landowner suffers the burning of his crops because his neighbour carelessly allows fire to spread from his land, another suffers the burning of his crops because his neighbour flicks a cigarette on to them while mending the fence between the two properties; and so on.
} 
the snow stops falling. If this regular or expected conduct fails to occur, then failure counts not, as the first world-view would suggest, as a non-intervention but rather, on a wider view of what amounts to change, as a sort of intervention in the world. If, as is often...the case, the break in routine violates a norm (the person who does not sweep up the snow may or may not have a duty to do so), it is a form of not-doing which amounts to an omission and is a potential ground of responsibility. ${ }^{60}$

This passage forms part of an explanation of how omissions can count as interventions in the world and thus give rise to liability. But it does more than this. It supports Honoré's contention that where there are distinct duties, omissions may be as bad as acts - to cause someone to slip and hurt herself by failing to clear away snow when one is under a duty to do so may be as bad as causing someone to slip by dropping a banana skin - and it shows that the maintenance of our security depends as much on people who owe us duties acting as we are entitled to expect (i.e. on their not harming us by their omissions) as it does on their refraining from positively acting so as to cause us harm. ${ }^{61} \mathrm{We}$ rely for our security as much on the performance of their duties by people who owe us positive duties to act as we do on people refraining from harming us. Society is a cooperative venture in which risky activities are undertaken and the risk is kept at an acceptable level both by requiring people to refrain from exacerbating the risk and by putting many people, including often public officials, under duties positively to act so as to avert, abate or minimise the risk. Our security rests on a pattern of expectations and if there is harm to it, it is as likely to be because of the omission to act as positive action.

There is thus nothing in Honoré's article to support the contention that harmful acts threaten security more than harmful omissions and much - the sound part of the article - to contradict it. What if there were an argument, however, that showed that acts were more of a threat to security than omissions? Nolan thinks the existence of such an argument shows that omissions by public authorities that are breaches of public law obligations and do not fall within one of the traditional exceptions to the omissions principle (as in the Stovin case) should not give rise to liability whereas

\footnotetext{
${ }^{60}$ Honoré n 10 above p 41.

${ }^{61}$ Note in this connection, a passage from Honoré's earlier work with Hart Causation and the Law ( $2^{\text {nd }}$ ed, OUP 1985) p 37: '[t]hough what is treated as normal represents in many ways our practical interests and our attitude to nature, it would be wrong to identify as the normal and so always as part of the "mere conditions" of events the course of nature unaffected by human intervention. This is an oversimplification, because what is taken as normal for the purpose of the distinction between cause and mere conditions is very often an artefact of human habit, custom or condition. This is so because men have discovered that nature is not only sometimes harmful if we intervene, but is also sometimes harmful unless we intervene, and have developed customary techniques, procedures, and routines to counteract such harm. These have become second "nature" and so a second "norm". The effect of drought is regularly counteracted by governmental precautions in conserving water or food; disease is neutralized by inoculation; rain by the use of umbrellas. When such man-made normal conditions are established, deviations from them will be regarded as exceptional and so rank as the cause of harm. It is obvious that in such cases, what is selected as the cause from the total set of conditions will often be an omission which coincides with what is reprehensible by established standards of behaviour...' The authors' primary concern in this passage is to show that omissions can be causes. But the passage also tends to support the view that, generally speaking, harm-causing omissions that take place in the context of distinct duties are no less serious than harm-causing acts.
} 
omissions that fall within one of traditional exceptions should. But an argument of this sort, if it existed, could just as well be taken to show that liability was inappropriate in the latter case as in the former.

If we look again at Nolan's presentation of Honoré's argument (described in the first paragraph of this section) we can see that it contains a number of curious features. These are worth remarking upon because they are probably the expression of a more widely held viewpoint than Nolan's alone. To begin with, in asserting that Lord Hoffmann's explanation of the omissions principle is inadequate, Nolan clearly has in mind its inability to justify the refusal of liability in the case of easy rescue ('circumstances in which to act would not be unduly burdensome and in which there are no or few other people who could render the assistance required'). As we have seen, however, to allow liability for easy rescue is not to negate the principle but merely to make another exception to it, an exception that can be justified, as can the more well established exceptions, on the ground that in the circumstances in question there is a distinct duty. Nolan's view of the omissions principle involves treating the principle together with the well-established exceptions as a package, one whose contents are fixed and immutable. ${ }^{62}$ Hence he thinks that to step outside the principle and the established exceptions is to reject the principle altogether. He appears not to recognize that the principle must have a rationale capable of justifying the exceptions to it as well as the principle itself and that, if this is so, it must be possible to make new exceptions if they too can be justified by reference to the rationale. One can only arrive at this position by reifying the principle and its established exceptions i.e. by treating them as sacrosanct and only addressing the reasoning that supports them as an afterthought.

\section{Tofaris and Steel's Position on Omissions}

Tofaris and Steel's reasons for rejecting the act/omissions distinction in its application to the police are broadly similar to those I have advanced: that public authorities do not have an interest in freedom in the sense that private persons do; that imposing liability for an omission in a particular case - the one that interests the authors being that of the police failing to protect a citizen from violence - does not undermine the omissions principle as a whole; that the particular case they have an in mind involves a distinct duty and forms an exception to the omissions rule rather than undermining it altogether; and that the 'why pick on me' argument has no application to a public authority where the authority exists for providing the very assistance that it is being impugned for not providing. They emphasise this last point by referring at a number of points in their article to the police's special status. ${ }^{63}$ This brings the police, and other public authorities, within the last exception to the principle as they formulate it. $^{64}$

\footnotetext{
${ }^{62}$ Wilberg conceives of the principle in the same way: see $\mathrm{n} 7$ above.

${ }^{63}$ Tofaris and Steele $\mathrm{n} 3$ above pp 129, 142, 145, 151.

${ }^{64}$ See $n 3$ above.
} 
While the arguments described in the previous paragraph resemble those I have made in this article, their authors do not apply them in the way that I would to the case that concerns them. If it is the status of the police that exempts them from the effects of the omissions principle then what does this status consist in? It consists, surely, in the fact that it is a public body charged with the task of protecting the public from crime and with special powers to enable it to perform this task. That being so, if the police are subject to duties in negligence to take care to positively assist citizens as well as to duties to take care not to harm them, it would be natural to regard these duties as continuous with or growing out of the duties and powers that define their status.

Tofaris and Steel do not use this mode of argument, however, in trying to explain why the police in the Michael case should have been subject to a duty of care. Instead they adopt a curious roundabout procedure. They argue for the existence of a moral duty to take care to prevent reasonably foreseeable physical injury to others which, they claim, gives rise in turn to a legal duty. ${ }^{65}$ Then, in order to explain why this duty applies only to public authorities and not to private individuals, they refer back to their discussion of the omissions principle and argue that while the rationale that underpins it does not exclude imposition of a duty of care on public authorities such as the police, it does exclude its imposition on private persons.

Two features of this argument are worth pointing out. Firstly, its roundabout character is odd. In considering the imposition on a landowner of a duty to take care to extinguish a fire on his land, or on a bar owner of a duty to prevent a drunk person from driving home, or on an employer of a duty to provide a safe system of work, it is not common practice to suggest a duty extending to all persons and then to try to narrow it down by reference to the fact that the putative defendant has a particular status while other persons do not. Usually, exemption from the omissions principle and being subject to a duty of care are both treated as following from the defendant's status.

Secondly, in order to succeed, the argument must begin by ascribing to citizens generally an extremely extensive duty, one equivalent to the duty that the police are alleged to be under in Michael. Tofaris and Steel never say in terms that private individuals are under a prima facie duty to disarm persons carrying out dangerous attacks on third parties. This must be what they are implicitly assuming, however, because their method is to begin with a moral duty that applies to everyone and then to whittle it down until they arrive at the legally enforceable duty on the police that they are seeking. Nothing in their argument augments by reference to their special powers the duty to which the police are subject. It might be said that the assumed moral duty only applies in the first place to those able to disarm a dangerous attacker. But suppose a group of strong men were apprised of an attack taking place somewhere in their neighbourhood: would we consider them to be subject to a moral duty to intervene as strong as the duty to which the police are subject? It is worth noting, moreover, that the existence of the extremely extensive duty I refer to here is deduced from an argument in favour of a duty of easy rescue of the sort that might be owed to a child drowning in shallow water. How the authors get from a duty of easy

${ }^{65}$ Tofaris and Steel n 3 above at pp 142-5. 
rescue to the much more onerous duty to protect someone from a dangerous criminal is never clear.

Shortly after setting out the argument described above for a duty on the police to aid those in danger, the authors attempt to explain how its scope would be limited by reference to the police's 'special' - i.e. public - legal powers. ${ }^{66}$ The end result is thus the same as that produced by the method of argument I suggested above was the correct one. One might ask, however: was it ever plausible to suggest that private individuals are under a prima facie duty to disarm persons carrying out dangerous attacks on third parties? And more generally: why was this circuitous method of argument adopted?

The reason seems to be a fear of mixing private and public law. That this is so appears from the reasoning Tofaris and Steel use in order to rebut another argument against finding a duty of care in the case that concerns them. ${ }^{67}$ The argument, deriving from another article by Nolan, is that making private persons but not public authorities subject to the omissions principle would introduce an 'alien public/private distinction' into the common law. ${ }^{68}$ The authors response to this is to accept the premise of the argument (that introduction of the 'alien' distinction would be undesirable) but to insist that the differential treatment of public authorities and private persons is one licenced by private law. But what justification is there for this fear of mixing public and private? The two are not clearly differentiated in English law as they are in some other systems ${ }^{69}$ and collateral challenge, whereby the public law legality of some act or omission of a public authority is tested by means of a private law challenge is a familiar phenomenon. ${ }^{70}$

\section{Conclusion}

If one assumes that a public authority's public law powers and duties can form the basis of a duty of care, then the problem of omissions vanishes. The omissions principle does not cease to apply, but there are clear grounds for making an exception to it where an authority has failed to do the very thing that it exists to do vis-à-vis the claimant. If one assumes that a public authority's public law powers and duties cannot form the basis of a duty of care, then a public authority can only be subject to liability

\footnotetext{
${ }^{66}$ ibid p 145.

67 ibid p 140.

${ }^{68}$ D Nolan 'Negligence and Human Rights Law: the Case for Separate Development' (2013) 76 MLR $286,317$.

${ }^{69} \mathrm{Cf}$ J Allison, A Continental Distinction in the Common Law (revised edition, OUP, 2000); D Oliver, Common Values and the Public-Private Divide (Butterworths, 1999); J Varuhas Damages and Human Rights (Oxford: Hart, 2016) part 2.

${ }^{70}$ As to which, see generally De Smith's Judicial Review ( $8^{\text {th }}$ ed, Sweet and Maxwell, 2018) 3-123 - 3132. See also R Clayton and H Tomlinson Civil Actions against the Police 3d edn (London: Sweet and Maxwell, 2004) chapter 4.
} 
for its omission to act where the omission falls within one of the established exceptions: the authority falls, in effect, to be treated just as if it were a private person for the purposes of identifying the factors that weigh in favour of a duty of care. If one attempts, as Tofaris and Steel do, to appeal to a public authority's status as a reason to make an exception to the omissions principle, then one is endorsing the position that a public authority's public law powers and duties can form the basis of a duty of care even if one does not admit that this is what one is doing.

The omissions principle is thus a red herring. The real issues are whether or not a duty of care can be based on a public authority's public law power and duties, in the sense explained above, and whether such a duty should be excluded on policy grounds.

It is a mistake to suppose that discussion of these matters can somehow be bypassed by focusing on the fact that where public authorities cause harm it is often by means of omissions. Honoré's claim that harmful acts represent more of a threat to security than harmful omissions is unfounded and does nothing to gainsay this conclusion. It is also a mistake to suppose that one could rely on a public authority's status as a public authority as a reason for denying the applicability of the omissions principle without at the same time recognizing that the authority's possession of public law powers and its subjection to public law duties form part of the reason for imposing on it a duty of care.

What I have described as the real issue is a large one and I do not attempt to deal with it here. Indeed, I do not think it could be adequately dealt with in the space of a journal article. The elimination of the omissions question is simply a piece of housekeeping, to be undertaken as an adjunct to the larger task. ${ }^{71}$

\footnotetext{
${ }^{71}$ The question of whether a duty of care can be based directly on a public authority's public law powers and duties is of course an aspect of a still larger question: should there be a specialized form of administrative liability in English law. In principle, if the answer to this question is affirmative, then the change to the current law might be brought about by creating an avenue of redress entirely distinct from the existing law of tort. Most proposals for creating some form of administrative liability made since the Anns case, however, have envisaged that at least part of the task would be fulfilled by developing the law of negligence: see e.g. JUSTICE-All Souls Review Administrative Justice: Some Necessary Reforms (Oxford, Clarendon Press, 1988) chapter 11; Law Commission Consultation Paper No. 187 Administrative Redress: Public Bodies and the Citizen; T Cornford Towards a Public Law of Tort (Ashgate, 2008).
} 